\title{
Application of the ESA (Engage, Study, Activate) Method in English Teaching for First Grade Students in Primary Schools
}

\author{
I Wayan Budiarta, Ni Wayan Kasni \\ \{budy4rt476@gmail.com $\}$ \\ Linguistic Masters Program, Warmadewa University
}

\begin{abstract}
This purpose of this paper is to explore the application of ESA method in English Teaching for Grade 1 Elementary Students. This method was applied to discover its effectiveness in assisting first grade elementary students in English teaching. Data were obtained from first grade Elementary Students in State Elementary Schools 2 and 3 Serangan, Denpasar. The teaching process was designed for eight meeting which lasted for two months or half a semester by applying the Engage, Study and Activate processes. Engage is the beginning of teaching activities in which the teacher or instructor attract students' interests through fun activities in the form of games. Meanwhile, in the Study, the teacher delivers the teaching material introduced in the Engage. Meanwhile, in Activate, the teacher tries to provide some exercises related to the topic for the students to use the language. The exercises provided in activate is also given through game and acts as the most effective way in the teaching process for the beginner. The result showed that the student is really active in the class because the teaching process is carried out in fun way. Furthermore, it enables students to raise their hands while answering answer the game or quiz-related questions given by the teacher. The students have the courage to speak even though only one or two words have been introduced, which indicates that the method is effective in the English teaching for first grade elementary students.
\end{abstract}

Keywords, engage, study, activate, game, English language teaching

\section{Pendahuluan}

Bali sebagai daerah tujuan wisata sudah sangat terkenal namanya di seleruh belahan dunia. Sebagai daerah tujuan wisata Pulau Bali sering kali disebut sebagai The Island of God, The Island of Thousand Temples, The Last Paradise (http://www.balitourismboard.org/), (cited 18 November 2019). Ketenaran nama Bali sebagai daerah tujuan wisata sudah sering kali mendapat penghargaan sebagai daerah tujuan wisata terbaik. Bali sebagai daerah tujuan wisata memiliki daya tarik tersendiri dibandingkan dengan daerah tujuan wsata lainnya baik di Indonesai maupun di dunia sehingga Bali memiliki daya tarik yang berbeda dengan daerah tujuan wisata lainnya yang membuta Bali sangat menarik untuk dikunjungi. Daya tarik yang dimiliki oleh Bali sebagai daerah tujuan wisata tidak hanya didukung leh alam yang begitu 
indah, namun juga didukung oleh adat, seni dan budaya masyarakat Bali yang merupakan satu kesatuan dalam kehidupan masyarakat Bali. Di samping Bali sebagai dawrah tujuan wisata dengan adatnya yang kuat yang tidak dapat dipisahkan dengan agama Hindu di Bali meruakan ciri khas yang membuat Bali berbeda dengan daerah tujuan wisata lainnya.

Bali sebagai daerah tujuan wisata sampai saat ini mengandalkan pariwisata budaya sebagai daya tarik utama wisatawan untuk datang ke Bali. Pariwisata yang dikembangkan di Bali berbasis kebudayaan sebagai objek kegiatan pariwisatanya. Hal ini mengacu pada Perda No 2 tahun 2012 tentang Kepariwisataan Budaya Bali. Budaya sebagai objek pariwisata di Bali mencakup agama, tradisi, musik, seni, makanan, dan sejarah. Di samping mengandalkan pariwisata budaya Bali terus mengembangkan pariwisata alternatif yang dapat menunjang kebrlangusngan pariwisata di Bali. Pariwisata alternatif merupakan uatu bentuk pariwisata yang mengutamakan nilai-nilai alam, sosial dan nilai-nilai masyarakat serta memungkinkan masyarakat lokal dan wisatawan menikmati interaksi yang positif dan bermanfaat serta menikmati pengalaman secara bersama-sama (Eadington \& Smith, 1992:3) di Bali. Bentukbentuk pariwisata alternatif mencakup kegiatan ekowisata, agrowisata, desa wisata dan wisata spiritual. Kedua jenis pariwisata ini menjadi andalan utama untuk dapat terus menarik dan meningkatkan kunjungan wisatawan yang berkunjung ke Bali. Keduanya saling melengkapi dan menjadi potensi yang terus dapat ditingkatkan sehingga menunjang keberlangsungan pariwisata di Bali yang merupakan isu sentral saat ini. Disamping kedua jenis pariwisata tersebut, pariwisata di Bali ditunjang dengan sarana dan prasarana yang sangat memadai, seperti hotel, villa, rumah makan, dan transportasi.

Bali sebagai daerah tujuan wisata yang mencakup delapan wilayah kabupaten dan satu kota, yaitu kota Denpasar sudah tentu memiliki daerah tujuan wisata yang diunggulkan untuk dapat menarik kunjungan wisatawan ke wilayahnya masing-masing. Setiap kabupaten di Bali memiliki daya tarik sendiri untuk menarik wisatawan berkunjung ke wilayahnya. Badung terkenal dengan Pantai Kuta, Pura Uluwatu, Nusa Dua, dan banyak objek lainnya. Tabanan terkenal dengan objek wisata Pura Tanah Lot, Desa jatiluwih, Kebun Raya Bedugul, dan objek lainnya. Gianyar terknal dengan kawasan Ubud, Riceterrace Tegallang, Monkey Forest, dan objek lainnya. Bangli memiliki objek wisata seperti kawasan Kintamani, Desa Penglipuran, Trunyan, dan objek lainnya. Klungkung dikenal dengan objek wisata kertha Gosa, Pulau usa penida, Pulau Nusa Lembongan, dan lainnya. Karangasem memilki objek wisata seperti Pura besakih, Tirtagangga, Pantai Amed dan objek lainnya. Singaraja yang terkenal dengan objek wisata Pura Pulaki, Pantai Lovina, Air Terjun Gitgit dan objek lainnya. Jembarana terknal dengan objek wisatanya seperti pantai Medewi, Pura Rambutsiwi, Taman Nasional Bali Barat, dan objek laiannya. Denpasar dengan obejk Wisatanya Pantai Sanur, Mueum Bali, Serangan, dan objek lainnya. Di samping obejk wisata yang nenarik untuk dikunjungi tiap wiayah di Bali juga memilki ataksi wisata yang mendukung objek-objek wisata di masing masing wilayah kabupaten di Bali.Sebagai ibukota Provinsi Bali, Denpasar juga memiliki daya tarik tersendiri untuk menarik kunjungan wisatawan untuk datang ke Denpasar. Dengan berbagai pilihan objek wisata yang ada, Denpasar juga terus berupaya untuk meningkatkan kunjungan wisatawan datang berkunjung ke Denpasar, Salah satu kawasan wisaa yang baru berkembang dan terus di kembangkan adalah Pulau Serangan. Pulau Serangan sebagai daerah tujuan wisata yang baru berkembang jika dibandingkan dengan kawasan wisata lain, seperti Sanur memerlukan perhatian lebih khusus dari pemerintah dan seluruh pemangku kepentingan supaya pariwisata di kawasan tersebut terus dapat bergeliat dan berkembang sehingga mampu meingkatkan ksejahteraan masyarakat di sana. Pulau Serangan sebagai daya tarik wisata memiliki pesona keindahan yang sangat menarik untuk dikunjungi. Selain sebagai pulau yang terkenal sebagai konservasi penyu, serangan juga terkenal akan wisata olah raga airnya, 
Banyak permainan yang ditawarkan seperti, paraselling, jetski, water ski, banana boat, seawalker, dan lainnya untuk dapat menarik kunjungan wisatawan ke Pulau Serangan. Di samping itu di Pulau Serangan juga terdapat Pura Sakenan yang juga menjadi daya tarik wisatawan untuk datang ke pulau Serangan.

Dengan peningkatan kunjungan pariwisata ke Pulau Serangan membawa dampak yang positif terhadap peningkatan kesejahteraan masyarakat. Peningkatan kesejahteraan masyarakat tersebut dapat dicapai apabila masyarakat dapat merasakan secara langsung dampak pariwisata. Untuk dapat merasakan dampak tersebut masyarakat harus ikut terlibat dan mampu memanfaatkan perkembangan pariwisata dengan berbagai kegiatan atau aktivitas yang dapat menunjang pariwisata tersebut. Untuk mendukung perkembangan pariwisata di Pulau serangan hendaknya didukung dengan Sumber Daya Manusia (SDM) yang memiliki keahlian di bidang pariwisata. Banyak keahlian yang terkait dengan upaya menunjang perkembangan pariwisata tersebut. Salah satu keahlian tersebut adalah keahlian di bidang bahasa asing. Kemampuan berbahasa asing memiliki peranan penting dalam dunia pariwisata mengingat wisatawan asing yang datang menggunakan bahasa asing. Salah satu bahasa asing yang paling banyak digunakan adalah Bahasa Inggris sehingga penguasaan bahasa Inggris menjadi sebuah keharusan sehingga pengenalan bahasa Inggris sejak usia merupakan langkah awal untuk menngkatkan minat dan motvasi belajar bahsa Inggris.

Sebagai daerah tujuan wisata dan merujuk pada kondisi anak-anak sekolah dasar di pulau Serangan memiliki kemapuan yang rendah dalam bahasa Inggris maka sebagai bentuk upaya peningkatan kemampuan bahasa Inggris terhadap anak-anak maka kegiatan Program kemitraan masyarakat (PKM) dengan tema "Menumbuhkan Minat Belajar Bahasa Inggris Siswa Sekolah Dasar Melalui Metode "ESA". Kegiatan ini bertujuan untuk meningkatkan minat belajar bahasa Inggris sejak sekolah dasar denga pengaplikasian metode ESA. Pemilihan metode ESA ini diharapkan mampu meningkatakn minat belajar baahsa inggris siswa sehingga ke depan tercipta Sumber Daya Manusia yang memiliki kemapuan berbahsa Inggris yang baik.

\section{Metode}

Kegiatan Pmebalajan bahasa Inggris bagi siswa sekolah dasar ini dilaksanakan dengan menrapak metode ESA yang dilaksanakan di dua sekolah dasar, yaitu Sekolah Dasar Neger 2 dan 3 Serangan. Metode ESA merupakan akronim dari Engage, Study, dan Activate yang merupakan tiga elemen penting dalam proses pembelajaran bahasa khususnya bahasa Inggris yang digagas oleh Harmer (1998, 25-26). Engage Study and Activate merupakan salah satu metode pembelajaran yang disajikan di dalam kelas untuk dapat membantu siswa dalam belajar lebih efektif. Engage adalah tahapan awal dalam kegiatan mengajar, yakni guru atau pengajar mencoba untuk membangkitkan minat siswa melalui kegiatan yang menyenangkan, misalkan Game. Game yang digunakan harus berkaitan dengan topik yang sedang didiskusikan dan topik itu mampu melibatkan siswa dalam proses pembelajaran tersebut

Pemilihan metode ini sebagai solusi di dasarkan pada pertimbangan bahwa metode ini memberikan kesempatan kepada siswa untuk megembangkan dan menggunakan pengetahuan bahasa yang dimiliki dan dikuasainya nya karena dalam metode ini siswa dituntut untuk berbicara aktif dan guru sebagai pengajar berfungsi sebagai activator. Engage dapat diartikan sebagai sebuah kondisi dimana guru tau pengajar membangkitkan atau menggugah perhatian peserta didik sehingga emosi siswa masuk dalam situasi belajar. Elemen ini merupakan 
elemen yang berfungsi untuk membuat emosi siswa itu senang dan tertantang sehingga mereka tidak merasa bosan namun justru siswa merasa mendapatkan situasi pembelajaran yang lebih baik. Sementara itu Study bisa dimaknai sebagai sebuah situasi dimana siswa diminta fokus pada informasi atau bahasa dan bagaimana informasi atau bahasa itu terbentuk. Dengan kata lain siswa terlibat dalam mengolah informasi dari bahan ajar baik informasi yang terkandung dalam suatu teks maupun unsur dan struktur kebahasaan yang terdapat dalam teks itu. Sehingga fokus utama dari elemen ini adalah teks dan struktur kebahasaan. Elemen terakhir adalah Activate yang menggambarkan latihan-latihan dan kegiatan-kegiatan pembelajaran yang dirancang sedemikian rupa sehingga siswa itu menggunakan bahasa itu secara bebas dan sekomunikatif mungkin. Pada elemen ini kegiatan pembelajaran tidak memfokuskan pada unsur-unsur kebahasaan namun mengajak siswa untuk menggunakan bahasa itu apakah bahasa itu berterima dalam keadaan dan situasi tertentu atau topik tertentu. (Harmer, 1998. 25-26).

\section{Hasil dan Pembahasan}

Seperti telah dijelaskan pada bagian metode bahwa kegiatan pembelajaran bahasa Inggris bagi siswa kelas satu sekolah dasar ini dirancang mengaplikasikan metode ESA.. Penerapan metode tersebut pada pembelajaran bahasa Inggris dilaksanakan melalui tiga tahapan, yaitu tahap Enggage, tahap Study, dan tahap Activate. tahap Engage (libatkan) dilakukan untuk memancing siswa berpikir dan berbicara dalam bahasa Bali, juga sebagai langkah awal menuju ke dalam pembelajaran. Selama fase Engage, guru berusaha untuk membangkitkan minat siswa dan melibatkan emosi mereka. Hal ini bisa dilakukan melalui permainan, penggunaan gambar, rekaman suara, dan video. Tahap berikutnya adalah Study, pada tahap ini Study, biasanya sebagian besar pelajaran berfokus pada inti pelajaran. Kegiatan pembelajaran dilaksanakan melalui pemberian materi. Sebelum melakukan kegiatan, diawali dengan proses DEGO (Demonstrate, Elicit, and Give Out). DEGO diawali dengan menunjukkan (Demonstrate) materi yang harus, menggali pengetahuan siswa agar mereka terlibat dalam pelajaran untuk mencegah kebosanan. Pada proses Elicit, guru tidak hanya memberikan informasi kepada siswa, tetapi menggali informasi dengan menggunakan pertanyaan, mencari huruf, dan lain-lain. Tahap terakhir adalah activate dimana pada tahap ini dilakukan dengan latihan dan kegiatan yang bertujuan untuk memancing siswa menggunakan bahasa secarai komunikatif sesuai kemampuan masing-masing. Pada tahap ini, siswa tidak difokuskan pada konstruksi bahasa atau pola praktek bahasa tertentu, tetapi menggunakan pengetahuan bahasa mereka dalam melaksanakan tugas.

Terdapat delapan topik bahasan yang diberikan kepada siswa kelas satu selama proses pembelajaram bahasa Inggris, yaitu (1) alphabet (huruf), (2) numbers (angka), (3) colours (warna), (4) day and Month (hari dan bulan), (5) part of body (bagian tubuh), (6) animals (binatang), (7) fruit and vegetables (buah dan sayuran), dan (8) Introducing (memperkenalkan diri). Berikut disajikan ketiga tahapan mengacu pada metode ESA yang dilaksanakan dalam proses pembelajaran dimaksud.

\section{(1) Alphabet (huruf)}

Topik ini merupakan materi paling dasar bagi setiap pelajar pemula apalagi siswa yang diajarkan saat ini merupakan siswa kelas satu. Tahap awal dari penerapan metode ESA ini 
adalah Engage. Sebagai awal proses pembelajaran, yaitu proses engage, pengajar membangkitkan minat dan menarik perhatian siswa dengan membuat game. Game yang diberikan dalam bentuk bantuan gambar berwarna buah atau binatang di mana gambar tersebut dilengkapi dengan di mana huruf pertama dari objek yang ditunjukkin dihilangkan dan meminta siswa untuk menebak huruf apa yang hilang. Dengan demikian pengajar secara otomatis mendapatkan perhatian dari siswa. Setelah itu pada tahap Study, dimana pengajar dengan bantuan audiovisual memutar video yang menampilkan pengucapan huruf a $-\mathrm{z}$ kemudian pengajar mengucapkan huruf tersebut dengan jelas dan minta kepada siswa untuk mengikutinya. Pada tahap ini pengajar meminta siswa untuk mengucapkannya secara berulang-ulang. Pengulangan ini merupakan hal yang penting bagi pelajar pemula (kelas 1 SD). Tahapan berikutnya adalah activate, pengajar kembali menggunakan metode game di mana siswa diminta untuk terlibat seccara aktif dalam kelas dengan cara siswa diminta melengkapi huruf yang hilang dalam setiap objek yang diberikan dan juga melafalkan hurufhururf tersebut dengan benar.

(2) Numbers (angka)

Pada topik ini pengajar menampilkan angka dan meminta anak anak untuk menyebutkan angka tersebut dalam bahasa Inggris. Pada tahap awal (engage) ini angka tersebut tidak diberikan tulisannya yang bertujuan untuk mendapatkan perhatian siswa. Angka yang diberikan mulai dari satuan dan puluhan. Setelah tahap tersebut pengajar menljutkan pengajaran dengan menunjukkan angka lengkap dengan tulisannya inilah tahap yang disebut sebagai tahap Study dimana siswa diminta belajar. Tahap ini juga didukung dengan pengajar memberikan pelajaran dalam bentuk audiovisual menggabungkan antara tampilan dan suara sehingga dapat menarik siswa untuk belajar. Setelah tahapan ini dilanjutkan dengan tahap activate. Pada tahap ini pengajar mencoba menggabungkan antara Enggage dan Study, Siswa diminta untuk menyebutkan angka yang ditunjukkan dalam melalui power point. Permainan yang diterpakan dalam pengajran ini adalah melengkapi bagiah dari huruf angka yang hilang dan juga siswa diminta mengucapkan angka dalam bahasa inggris dengan benar.

(3) Colours (warna)

Pada tahap Engage, pengajar menunjukan beberpa obejk yang di berikan dengan warna yang berbeda beda. Tahap ini pengajar mencoba menggiring siswa bahwa pelajaran hari ini yang diberikan adalah tentang warna. Berbgai macam warna dikenalkan kepada siswa memlaui bantuan gambar dengan bantuan LCD projector. Pada tahapan ini siswa hanya diminta untuk menyebutkan nama warna saja belum pada tahapan di mana siswa diminta untuk menulis nama warna yang diberikan. Setelah hal tersebut dilakuakn selama 15 menit, kemudian tahap berikutnya, yaitu study di mana siswa diberikan secara penuh warna dan tulisannya sehingga siswa dapat membaca dan mengucapkannya. Setelah itu dilanjutkan dengan kegiatan dimana siswa diajak bermain tentang warna. Siswa diminta untuk melengkapi huruf yang hilang dalam tulisan warna yng ditampilkan. Siswa.

(4) Day and Month (hari dan bulan)

Tahap engage pengajar menampilkan nama hari dan dilanjutkan dengan nama bulan. Siswa diberikan materi dalam bentuk power point dengan menyajikan nama hari dan bulan dalam huruf dengan warna yang berbeda. Hal ini dilakukan untuk menarik perhatian siswa bahwa pelajaran hari ini adalah tentang hari dan bulan. Tahap selanjutnya adalah pengajar kembali menampilkan nama hari dan bulan namun kali ini pengajar mengucapkannya dan meminta siswa untuk mengikuti mengucapkannya. Hal ini penting dilakukan pengajar secara berulang-ulang karena siswa masih tergolong masih pemula. Pengulangan dalam pembelajaran bagi pemula merupakan hal yang sangat penting. Setelah tahap Study dilalui, amak pengajar lanjut ke tahap activate dimana pengajar memberikan permainan dalam bentuk 
quis dan meminta siswa untuk melengkapi setiap nama hari dan bulan yang dihilangkan satu atau dua hurufnya. Di samping itu, siswa juga di minta mengatur urutan hari dan bulan dari awal sampai akhir.

(5) Part of body (bagian tubuh)

Tahap engage ditandai dengan pengajar memberikan gambar tubuh manusia dengan bantuan LCD projector. Tahap ini pengajar coba memencing siswa dengan pengetahuan yang dimilki untuk menyebut bagian tubuh yang ditandai dalam gambar. Hal ini dilakukan untuk menarik dan mendapatkan perhatian dari siswa. Siswa di minta untuk menyebutkan bagian tubuh tersebut. Selanjutnya pada tahap study, pengajar memiliki peran sentral dalam proses pembelajaran di mana pengajar mengucapkan atau menyeburkan bagian tubuh yang ditunjuknya. Hal ini juga dilakukan berulang-ulang untuk membantu siswa untuk lebih mengingat materi yang diberikan. Setelah dua tahapan ini selesai dinajutkan dengan tahapan activate, tahap ini siswa diminta untuk meju ke depan kelas untuk menyebutkan bagian tubuhnya satu persatu minimal 5 bagian tubuh yang harus disebutkan. Bagi yang berhasil menyebutkan diberikan hadiah.

(6) Animals (binatang

Tahap awal pembelajaran ini diawali dengan pengajar menampilkan gambar-gambar binatang. Gambar binatang yang ditampilkan adalah binatang yang sering mereka jumpai baik dirumah maupun di kebun binatang. Pada tahap awal ini hanya gambar saja yang ditampilkan hal ini dilakukan untuk memancing siswa supaya aktif di kelas. Pada tahapan study pengajar menampilkan gambar binatang beserta tulisannya. Pengajar kemudian mengucapkan atau menyebutkan nama binatang yang ditampilkan dan siswa diminta untuk mengulanginya. Kombinasi antara gambar dan tulisan lebih mempermudah siswa untuk mengingatnya. Metode ini sangat efektif dilakukan untuk pelajar pemula. Tahapan terakhir adalah activate. Tahap ini pengajar memberikan semacan game dalam bentuk quis. Satu ssiwa di minta untuk menirukan gerak gerik sebuah binatang dan siswa yang lain diminta untuk menebaknya. Susana belajar dalam kelas akan terasa lebih menyenangkan dan hal inilah yang membantu siswa untuk belajar lebih efektif karena mereka melakukannya dengan suka cita dan penuh kegembiraan.

(7) Fruit and Vegetables (buah dan sayuran)

Tahap ini diawali dengan menampilkan gambar buah dan sayuran. Tampilan gambar buah dan sayur ini tanpa dilengkapi dengan tulisannya dan siswa diminta untuk mnyebutkan nama buah atau sayuran yang ditunjukin oleh pengajar. Gambar buah dan sayuran ditampilkan dengan warna yang tujuaanya untuk menarik perhatoian siswa. Tahapan inilah yang disebut dengan engage dimana siswa supaya berada dalam situasi belajar yang baik. Pada tahap study, pengajar memiliki peran yang dominan untuk menyampaikan materi pelajaran kepada siswa. Pada tahap ini pengajar menyampikan berbagai jenis buah dan sayuran. Pengajar dalam hal ini kembali menampilkan gambar buah dan sayuran yang telah dilengkapi dengan tulisannya. Pengajar kemudian mengucapkannya dan diikuti oleh siswa. Pada activate, pengajar memberikan quiz menebak nama buah atau sayuran yang diperlihatkan gambarnya. Dengan demikian siswa menjadi lebih aktif dalam proses pembelajaran sehingga hasilnya lebih maksimal.

(8) Introdusing (memperkenalkan diri)

Pada tahapan engage, pengajar memperkenalkan dirinya sendiri untuk memberikan contoh kepada siswa. Kemudian pengajar meminta kepada siswa untuk melakukan hal yang sama. Hal ini dilakukan untuk melihat sejauh mana siswa mampu memperkenalkan dirinya. Tahap selanjutnya adalah pengajar menjelaskan bagaimana cara memperkenalkan diri dan kemudian memuutarkan video yang berisi cara memperkenalkan diri, Tahap terakhir dari pembelajaran ini adalah memenita siswa untuk meperkenalan diri kembali untuk melihat 
pemahaman siswa. Pemberian hadiah unutk adalah salah satu model dalam rangka pemberian penghargaan kepada anak-anak sehingga menjadi lebih emnarik bagi anak-anak.

Hasil dari penerapan metode ESA dalam proses pengajaran bahasa Inggris siswa kelas 1 di dua sekolah dasar tersebut menunjukkan hasil yang sangat baik. Hal ini dapat dilihat aktivitas dan interaksi siswa dengan pengajar dalam proses pembelajaran. Dapat dilihat bahwa siswa merasa senang karena setiap pelajaran yang diberikan selalu diawali dengan sesuatu yang menyenangkan yang diwujudkan dalam bentuk game. Situasi belajar seperti ini memeprolhe hasil yang lebih efektif. Siswa merasa seanang dan gembira ketika mereka melalui proses pembelajaran. Mereka seolah-olah merasa tidak belajar tapi bermain. Efektifitas metode ini secara nyata dapat dilihat ketika siswa mulai berani berbicata dan menjawab setiap pertanyaan yang dibrikan dalam bentuk game. Siswa sudah berani berbicara satu dua kata dalam bahasa Inggris. Hal ini menunjukkan paling tidak dengan merode ini ada peningkatan aktivitas dan minat siswa dalam proses pembelajaran bahasa Inggris.

\section{Kesimpulan}

Mengacu pada uraian di atas dapat disimpulkan bahwa proses pembalajaran bahsa Ingris pada siswa kelas satu Sekolah Dasar negeri 2 dan 3 Serangan mengaplikasikan metode ESA yang terdiri atas 3 tahapan, yaitu engage, study, activate. Pada tahap engage tujuannya adalah bagaimana melibatkan siswa dalam kelas. Pelibatan ini maksudnya adalah bagaimana seorang pengajar mampu menciptakan suasana belajar dimana siswa merasa terlibat dan merasa senang dalam proses pembelajaran sehinga mendapatkan perhatian dari siswa tersebut. Mendapatkan perhatian siswa dalam proses pembelajaran merupakan hal yang tidak mudah dilakukan. Pada tahap Study pengajar lebih memiliki oeran yang lebih dominan karena oengajar akan memberikan materi sesuai dengan topic yang diberikan, pada tahap ini materi yang diberikan ditampilkan dalam bebrgai bentuk media, seperti power point dan audiovisual, pada tahap activate meruapakan perpaduan dari tahap engage dan study di mana pengajar mencoba untuk membuat aktivitas diman siswa mampu mengalikasikan apa yng telah mereka pelajari. Hasil dari penerapam metode ESA menunjukkan bahwa metode ini efektif untuk meningkatkan aktivitas siswa dalam kelas. Siswa menjadi lebih aktif dalam kelas karena mereka merasa terlibat dan juga siswa memiliki keberanian untuk menggnakan bahasa inggris walau hanya satu dua kata. Situasi ini berbeda ketika metode konvensiona digunakan, dimana pengajar masuk kelas dan lansung memberikan materi.

\section{References}

[1] Brown, Douglas. H. (2003). Language Assesment, Principle, and Classroom Practice. San Fransisco, USA: Prentice Hall Inc.

[2] Buttmer, Amy. (2013). Aktivitas Permainan dan Strategi Penilaian untuk Kelas Bahasa Asing. Jakarta: PT Indeks.

[3] Djamarah, Syaiful Bachri. (1996). Strategi Belajar Mengajar. Jakarta: Rineka Cipta

[4] Freeman, D.L., (2004). Techniques and Principal in Language Teaching. Second Edition. New York. Oxford University Press.

[5] Hardiyanti, Erika. (2014). "Pengaruh Metode ESA (engage, study, activate) terhadap Keterampilan Berbicara Siswa pada Pembelajaran Bahasa Inggris”. (skrips). Bandung: Universitas Pendidikan Indonesia 
[6] Harmer, Jeremy (1998). How To Teach English, An Introduction To The Practice Of English Language Teaching, Longman.

[7] Nunan, David. (1992). Research Methods in Language Learning. London: Cambridge University Press.

[8] Peraturan Daerah Provinsi Bali Nomor 2 Tahun 2012 Tentang Kepariwisataan Budaya Bali.

[9] Ruki, Made. 2008. "Pengembangan Pariwisata Spiritual di Ashram Gandhi Puri Sevagram, Klungkung, Bali " (tesis). Denpasar: Universitas Udayana.

[10] Smith, Valene L. and Eadington, William R. 1992. Tourism Alternatives Potentials and Problems in the Development of Tourism. England: Wiley \& Sons Ltd. 